\title{
Capabilities, Political Liberalism and Private Law
}

\begin{abstract}
This article argues political liberalism can and should be revised to improve its relevance to the private law. This approach is not a rejection of political liberalism, but instead a restatement consistent with the fundamental tenets of Rawls's theory of justice. The first part begins with a brief summary of Rawls's political liberalism. The second part discusses the strategies used to demonstrate the relevance of Rawls's theory to the private law. The third part examines how Rawls's theory can and should be revised by incorporating capabilities. I argue this revision can be undertaken in a way that best develops the relevance of political liberalism. Keywords: capabilities, liberalism, Nussbaum, political liberalism, private law, Rawls, Ripstein Schlagworte: Fähigkeiten, Liberalismus, Nussbaum, Politischer Liberalismus, Privatrecht, Rawls, Ripstein
\end{abstract}

\section{Introduction}

John Rawls's political liberalism remains a dominant contribution to our current debates about justice. ${ }^{1}$ It has been said that we 'must either work within Rawls' theory or explain why not' and this is no less true more than a decade after his passing. ${ }^{2}$ Rawls develops political liberalism from the idea of the citizen begins with 'the idea of society as a fair system of social cooperation over time' across generations supplemented by 'two companion fundamental ideas.' The first is the idea of citizens as free and equal persons. Every system must respect this conception of citizens or it is unfair and so unjust. The second is the idea of a well-ordered society understood as 'a society effectively regulated by a public conception of justice.'

Rawls's political liberalism has attracted widespread attention as a theory of public justice, but its importance for areas such as the private law is relatively neglected although there is a growing interest in improving our understanding of its application. Several commentators attempt to apply Rawls's theory of justice to our understanding

$1 \quad$ See John Rawls, Political Liberalism, paperback edn (New York: Columbia University Press, 1966) (hereafter PL); John Rawls, A Theory of Justice, rev. (Oxford: Oxford University Press, 1999) (hereafter TJ) and John Rawls, Justice as Fairness: A Restatement, ed. Erin Kelly (Cambridge: Harvard University Press, 2001) (hereafter $J F$ ).

2 Robert Nozick, Anarchy, State and Utopia (New York: Basic Books, 1974): 183.

$3 \mathrm{JF}, 5$.

4 Ibid. 
of contract law and tort law to illuminate how it might inform and reform our current practices. ${ }^{5}$ Some attempts, most notably work by Arthur Ripstein, demonstrate wider implications for tort law as well. ${ }^{6}$ Nonetheless, disagreement remains concerning central issues about the precise relevance of Rawls's political liberalism to the private law where a common focus remains on how the former may contribute to revising the latter.

This article argues political liberalism can and should be revised to improve its relevance to the private law. This approach is not a rejection of political liberalism, but instead a restatement consistent with the fundamental tenets of Rawls's theory of justice. The article seeks to build on Ripstein's interpretation of Rawls in connection with private law. It is argued that a Rawslian account of private law can be improved if we adopt a revision of Rawls's political liberalism incorporating capabilities in a way that is more consistent with his theory of justice than others have tried to combine political liberalism with capabilities in the past, such as Martha Nussbaum. Ripstein is correct that Rawls can offer a powerful account of private law, but this article goes further to show how we might revise Rawls's account in a way that is faithful to his overall theory that can provide us with a more compelling view.

The first part begins with a brief summary of Rawls's political liberalism. The second part discusses the strategies used to demonstrate the relevance of Rawls's theory to the private law. The third part examines how Rawls's theory can and should be revised by incorporating capabilities. I argue this revision can be undertaken in a way that best develops the relevance of political liberalism to private law in a compelling restatement.

\section{Rawlsian Justice}

Rawls's political liberalism is a theory about justice with the idea of citizens as free and equal engaged in a fair system of cooperation at its heart. ${ }^{7}$ Citizens hold reasonable, but incompatible reasonable comprehensive doctrines about religious, philosophical and moral matters. Rawls calls the differences between citizens over comprehensive doctrines a 'fact of reasonable pluralism' and it is neither exceptional nor rare, but a characteristic feature of modern societies. ${ }^{8}$ Reasonable pluralism is a challenge for securing

5 For example see Ronan Avraham, 'Accident Law for Egalitarians', Legal Theory 12 (2006): 181-224; Gregory C. Keating, 'Rawlsian Fairness and Regime Choice in the Law of Accidents', Fordham Law Review 72 (2004): 1857-921; Gregory C. Keating, 'Personal Inviolability and "Private Law", Journal of Tort Law 1 (2007): 4-40; Kevin Kordana and David Trabachnick, 'Rawls and Contract Law', George Washington Law Review 73 (2005): 598-632; Kevin Kordana and David Trabachnick, 'On Belling the Cat: Rawls and Tort as Corrective Justice', Virginia Law Review 92 (2006): 1279-310 and Benjamin Zipursky, 'Rawls in Tort Theory: Themes and Counter-Themes', Fordham Law Review 72 (2004): 1923-40.

6 Arthur Ripstein, 'Private Order and Public Justice: Kant and Rawls', Virginia Law Review 92 (2006): 1391-438.

$7 \mathrm{JF}, 5$.

8 See John Rawls, 'The Idea of Public Reason Revisited' in The Law of Peoples (Cambridge: Harvard University Press, 1999): 131 (hereafter $L P$ ); JF, 3-4, 33-34, 36, 40, 84 and $P L, 24-25$ n227, 63-64, 129, 140, 144, $147-48,172$. 
political stability: if free and equal citizens have reasonable disagreement about preferences for different and conflicting comprehensive doctrines, this difference could undermine political stability over time. ${ }^{9}$ We require a political conception that addresses this concern.

Rawls claims his earlier $A$ Theory of Justice suffers from this 'serious problem' because it did not account for reasonable pluralism. ${ }^{10}$ In Political Liberalism, he defends a solution to this problem designed to secure political stability while retaining his commitment to the idea of citizens as free and equal. Rawls's solution is that citizens should construct an overlapping consensus built from public reasons that could be acceptable to each." The fact of reasonable pluralism renders impossible our prioritizing one comprehensive doctrine over others without failing to respect the equality of citizens and the differences that exist about doctrine preferences. ${ }^{12}$ An overlapping consensus cannot promote any particular comprehensive doctrine as a result.

This consensus is a shared conception of political justice that each citizen affirms through the use of 'public reason': claims we may reasonably offer others for mutual acceptance..$^{13}$ Public reasons may not settle all political questions, but they are the only satisfactory kind of reason and so essential to the public justification of a shared political conception of justice. ${ }^{14} \mathrm{~A}$ political conception may be shared where it is reasonable to expect others to acknowledge its justification: 'it must be acceptable, not only to our own considered convictions, but also to those of others.'15 Public reasons help to ensure our shared political conception secures reciprocity between citizens on fair terms of cooperation respecting each as free and equal..$^{16}$

An overlapping consensus is a shared political conception of justice because it is not a rival 'comprehensive' view and its acceptance does not require special commitment to any particular doctrine. ${ }^{17}$ This consensus secures political stability 'for the right reasons' because each citizen can endorse a shared political conception as reasonable and not purely in terms of their individual self-interest. ${ }^{18}$ Individual preferences for comprehensive doctrines need not be comprised nor is stability achieved through coercion or a

9 It is essential that comprehensive doctrines are 'reasonable' and my discussion will only consider reasonable comprehensive doctrines. See $P L, 58-59$.

$10 P L$, xviii. See ibid., xxvii, 3-4.

11 JF, 32-38 and PL, 133-72. See Samuel Freeman, Rawls (London: Routledge, 2007): 366-71; Sebastiano Maffetone, Rawls: An Introduction (Cambridge: Polity, 2010): 261-74 and T. M. Scanlon, 'Rawls on Justification' in Samuel Freeman (ed.), The Cambridge Companion to Rawls (Cambridge: Cambridge University Press, 2003): 159-61.

$12 J F, 9$.

13 See John Rawls, 'Justice as Fairness' in Collected Papers, ed. Samuel Freeman (Cambridge: Harvard University Press, 2001): 208 (hereafter CP).

14 See JF, 26-27, 91; PL, liii, 163 ('I stress the significance of the role of public reason') and Chad Flanders, 'The Mutability of Public Reason', Ratio Juris 25 (2012): 180 ('It seems no exaggeration to say that, for Rawls, without public reason there would be no political liberalism').

$15 \mathrm{JF}, 27$.

16 See Rawls, 'The Idea of Public Reason Revisited' in LP, 132-33, 136; PL, 16-17 and TJ, 29-30.

$17 \mathrm{JF}, 33,37$ and $P L, 13$. See $P L$, xxix ('Political liberalism is not comprehensive liberalism').

$18 P L$, xxxix, xli-xliii, $147-48$ and see 54 ('This reasonable society is neither a society of saints nor a society of the self-centred'). 
temporary truce. ${ }^{19}$ For Rawls, only an overlapping consensus justifies political stability for the right reasons in terms that free and equal citizens can affirm as reasonable irrespective of which comprehensive doctrine each accepts.

Rawls's proposed solution of an overlapping consensus has received much criticism. Some, such as Kurt Baier, Brian Barry, George Klosko and Edward McClennen, argue it is unnecessary. Rawls should have acknowledged existing resources in his account that might secure political stability over time without major changes to his original views about justice..$^{\circ}$ Other critics, such as Kent Greenawalt, Michael Sandel, Leif Wenar and Iris Marion Young, argue an overlapping consensus is too fragile to secure political stability. While Rawls might have identified a major problem for his original account, he fails to provide a satisfactory solution. ${ }^{21}$

I argue elsewhere that these objections rest on a mistake easily made that, for Rawls, the possibility of future political stability is guaranteed by an overlapping consensus alone. This perspective fails to recognise additional resources available to Rawls that can help secure political stability. ${ }^{22}$ These features further substantiate political liberalism as a theory about political justice.

One resource is the idea of 'reciprocity' which helps forge an important social bond among citizens. ${ }^{23}$ Political equality serves the purpose of guaranteeing a sufficient level of reciprocity among citizens 'fundamental to both justice and fairness.' ${ }^{24}$ Leif Wenar says:

The use of political power must fulfil a criterion of reciprocity: citizens must reasonably believe that all citizens can reasonably accept the enforcement of a particular set of basic laws. Those coerced by law must be able to endorse the society's fundamental political arrangements freely, not because they are dominated or manipulated or kept uninformed. ${ }^{25}$

Rawls's criterion of reciprocity can be understood as a form of mutual recognition. ${ }^{26}$ Citizens do not merely view each other as having an equal voice; but, more importantly,

19 See JF, 192-93.

20 See Kurt Baier, 'Justice and the Aims of Political Philosophy', Ethics 99 (1989): 771-90; Brian Barry, 'John Rawls and the Search for Stability', Ethics 105 (1995): 874-915; George Klosko, 'Rawls's Argument from Political Stability', Columbia Law Review 94 (1994): 1882-97 and Edward F. McClennen, 'Justice and the Problem of Stability', Philosophy and Public Affairs 18 (1989): 3-30.

21 See Kent Greenawalt, 'Some Problems with Public Reason in John Rawls's Political Liberalism', Loyola of Los Angeles Law Review 28 (1995): 1303-17; Michael Sandel, 'Political Liberalism', Harvard Law Review 107 (1994): 1765-94; Michael Sandel, Liberalism and the Limits of Justice, $2 \mathrm{~d}$ edn (Cambridge: Cambridge University Press, 1998): 184-218; Leif Wenar, 'Political Liberalism: An Internal Critique', Ethics 106 (1995): 32-62 and Iris Marion Young, 'Rawls's Political Liberalism', Journal of Political Philosophy 3 (1995): 181-90, esp. 184-85.

22 See Thom Brooks, 'The Capabilities Approach and Political Liberalism' in Thom Brooks and Martha C. Nussbaum (eds), Rawls's Political Liberalism (New York: Columbia University Press, 2015): 139-173.

23 See JF, 139 ('The least advantaged are not, if all goes well, the unfortunate and unlucky - objects of our charity and compassion, much less our pity - but those to whom reciprocity is owed as a matter of political justice among those who are free and equal citizens along with everyone else').

$24 J F$, 209. See Rawls, 'Justice as Reciprocity' in CP 209.

25 Leif Wenar, 'John Rawls', Stanford Encyclopedia of Philosophy (website: http://plato.stanford.edu/entries/ rawls).

26 See JF, 8 and Thom Brooks, 'Reciprocity as Mutual Recognition', The Good Society 21 (2012): 21-35. Rawls elsewhere refers to 'reciprocal recognition' $(T J, 48)$. 
as having a voice that should be heard and considered in reciprocal engagement with others. The social bonds arising from reciprocity and mutual respect generate their own support over time. ${ }^{27}$ The more that citizens gain in confidence about the strength of their mutual connections, the more their ties become cemented.

Reciprocity among citizens requires all parties endorse two principles of justice and this provides a second source of connection that can helps foster political stability over time. These principles are:

(a) Each person has the same indefeasible claim to a fully adequate scheme of equal basic liberties, which scheme is compatible with the same scheme of liberties for all; and

(b) Social and economic inequalities are to satisfy two conditions: first, they are to be attached to offices and positions open to all under conditions of fair equality of opportunity; and second, they are to be to the greatest benefit of the least- advantaged members of society. ${ }^{28}$

The first principle has lexical priority over the second. ${ }^{29}$ Any social and economic inequalities are only justifiable where each citizen enjoys equal basic liberties among other conditions. Rawls claims our basic liberties include 'freedom of thought and liberty of conscience; political liberties (for example, the right to vote and to participate in politics) and freedom of association' and 'the rights and liberties covered by the rule of law'.3 Our mutual support of basic liberties is an essential social bond and political stability may be undermined when it is unsecured.

A final, additional resource for Rawls's theory that can promote political stability is the satisfaction of a social minimum of primary goods guaranteed to each citizen. Rawls defines our 'primary goods' in terms of 'what persons need in their status as free and equal persons, and as normal and fully cooperating members of society over a complete life. ${ }^{31}$ These goods include:
A. Basic rights and liberties, also given by a list;
B. Freedom of movement and free choice of occupation against a background of diverse op- portunities;
C. Powers and prerogatives of offices and positions of responsibility in the political and eco- nomic institutions of the basic structure;
D. Income and wealth; and finally,
E. The social bases of self-respect. ${ }^{32}$

It is crucial that every citizen possess primary goods above the threshold of a 'social minimum. ${ }^{33}$ Each citizen need not have the same amounts of primary goods above this threshold as social and economic differences above this level can be justified. Citizens

$27 \mathrm{JF}, 194$ and $P L, 140$.

$28 \mathrm{JF}, 42-43$.

$29 \mathrm{JF}, 43$ and $T J, 53$.

30 Ibid.

31 TJ, xiii.

32 PL, 181.

33 See TJ, 243, 267 and $P L, 228-29$. 
that possess primary goods above a social minimum secure 'the needs essential for a decent human life. ${ }^{34}$ For Rawls, the idea the citizen as free and equal requires satisfaction of the social minimum because it enables all citizens to conceive themselves a part of political society. Political stability is impossible over time where the social minimum threshold is not met. The guarantee of the social minimum is a key connection helping secure political stability surprisingly overlooked by critics and perhaps also by Rawls. ${ }^{35}$

Rawls defends a theory of justice based on the idea of citizens as free and equal engaged in a fair system of cooperation. His challenge is to guarantee their standing as free and equal while addressing the problem that citizens will possess diverse and incompatible comprehensive doctrines. This is a problem because it is unclear how political stability over time can be guaranteed in the light of such disagreement. Rawls's solution is to defend an account of political liberalism whereby citizens endorse an overlapping consensus constructed through the use of public reasons that each may endorse. This consensus is claimed to offer a social bond that makes political stability possible without undermining the freedom and equality of citizens. Rawls's solution has attracted several critics who largely overlook additional resources in political liberalism that can help secure political stability, such as the criterion of reciprocity, the two principles of justice and the satisfaction of a social minimum of primary goods.

Whether or not his solution is successful, Rawls's focus appears centred on the social and political character and interaction of citizens in public spaces. The relevance of Rawls's political liberalism for private law remains obscure and uncertain.

\section{Rawlsian Private Law}

This part considers two arguments about how we should relate Rawls's political liberalism to private law following positions previously defended by Ripstein. The discussion's aim is to make his position his arguments for it clear. Section 3 argues that, if we accept Ripstein's convincing arguments, we can revise a central part of Rawls's account in order to render it more compelling. ${ }^{36}$

The first argument claims that Rawls defends two different types of obligations at work in his theory. Ripstein claims this distinction can be found in Rawls's work and helps link his theory of justice to private law. Rawls says:

[S]ociety, the citizens as a collective body, accepts the responsibility for maintaining the equal basic liberties and fair equality of opportunity ... while citizens (as individuals) ... accept the

$34 J F, 129$.

$35 \mathrm{JF}, 3$. See Frank I. Michelman, 'Poverty in Liberalism: A Comment on the Constitutional Essentials', Drake Law Review 6o (2012): 101-21. Note that, for Rawls, we must both satisfy the Difference Principle and maintain a social minimum of primary goods.

36 My argument is not that Ripstein's (or Scheffler's) account of Rawls's theory is problematic, but that Rawls's theory in connection with private law can be improved further by building on the arguments found in Ripstein's interpretation. I am grateful to an anonymous referee for helping to clarify this point. 
responsibility for revising and adjusting their ends and aspirations in view of the all-purpose means they can expect, given their present and foreseeable situation. This division of responsibility relies on the capacity of persons to assume responsibility for their ends and to moderate the claims they make on their social institutions in accordance with the use of primary goods. Citizens claims to liberties, opportunities and all-purpose means are made secure from the unreasonable demands of others. ${ }^{37}$

Ripstein argues these different types of responsibilities refer to different kinds of law. There is a contrast between the responsibility of citizens qua individuals for their particular pursuits and the responsibility of citizens considered together in a state for guaranteeing basic liberties and the opportunities to make these pursuits possible. ${ }^{38}$ These responsibilities correspond generally to the spheres of private and public law. ${ }^{39}$ Ripstein claims that Rawls's idea of responsibility of citizens qua individuals helps provide us with 'a distinctive way of thinking about human freedom and independence' relevant to our understanding of private law..$^{40}$

This distinction of two types of responsibilities highlights the dual identities each citizen possesses that a theory about political justice should capture. Citizens stand in two different relations to each another linked to a distinctive responsibility. Citizens engage in constructing a fair system of social cooperation. This is the perspective of the citizen as the public member of a political community where relations are informed by all. Citizens occupy this perspective when constructing an overlapping consensus through the use of public reasons. Their relations are subject to reasons that can be endorsed by everyone here and now.

Citizens possess a second relation to each other as private individuals concerning non- public matters relating to their pursuit of their own ends. This second perspective is complimentary to the first. Both address citizens from different perspectives that aim to capture the full range of individual responsibilities relevant for a fair system of cooperation between citizens. It is unclear that these two perspectives never pull in different directions in borderline cases. If these perspectives were incoherent to some degree, then this might constrain the exercise of individual responsibility in one or both senses and serve to undermine this dichotomy about the kinds of responsibilities that citizens possess.

Rawls accepts a conception of social cooperation that extends beyond the domain of the purely public. His conception includes three features. The first is that 'social cooperation is guided by publicly recognized rules and procedures which those cooperating accept as appropriate to regulate their conduct.. ${ }^{41}$ This feature is consistent with the idea

37 John Rawls, 'Social Unity and Primary Goods', in Amartya Sen and Bernard Williams (eds), Utilitarianism and Beyond (Cambridge: Cambridge University Press, 1982): 159-85, at 170 (cited in Ripstein, 'Private Order and Public Justice', 1396).

38 Ripstein, 'Private Order and Public Justice', 1396.

39 The relation of Rawls's political liberalism to private law is an object of interpretive reconstruction. This is because Rawls fails to provide any unambiguous, extended discussion in his work. See TJ, 211-13 and PL, 282-85.

40 Ripstein, 'Private Order and Public Justice', 1398.

$41 \mathrm{JF}, 6$. 
of private law as distinct from public law, but where both are composed of regulations that are publicly acknowledged and 'acceptable as appropriate' by cooperating citizens. ${ }^{42}$ The second feature is that 'fair terms of cooperation specify an idea of reciprocity or mutuality' and the third is that those engaged in cooperation relate to others 'from the standpoint of their own good'.43 Together, these three features of social cooperation extend beyond the purely public sphere and may include the private sphere subject to certain conditions.

Rawls appears to accept the 'open texture' of the idea of social cooperation where its features form a coherent unity. This does not require our denying the distinction of public law and private law so long as we recognise their common link. Rawls says:

the spheres of the political and the public, and of the not-public and the private, take their shape from the content and application of the conception of justice and its principles. If the socalled private sphere is a space alleged to be exempt from justice, then there is no such thing. ${ }^{44}$

The private sphere can exist as a separate domain from the public if, and only if, its content is shaped and consistent with political liberalism. Each side can exist provided neither denies citizens their freedom and equality, enjoyment of two principles of justice, reciprocity and attainment of a social minimum. This link between public and private in terms of a shared link in political justice is essential. One implication is that, if we accept that Rawls endorses two different types of responsibility, we must ensure each type shares this common bond in some coherent way.

A second argument connecting Rawls's political liberalism to private law focuses on the importance of each citizen's two moral powers. ${ }^{45}$ Rawls argues that citizens must reside above a social minimum of primary goods in order to secure 'the adequate development and full exercise of their two moral powers and a fair share of the all-purpose means essential for advancing their determinate (permissible) conceptions of the good'. ${ }^{6}$ The first moral power is the capacity for a sense of justice defined as 'the capacity to understand, to apply, and to act from (and not merely in accordance with) the principles of political justice that specify terms of social cooperation. ${ }^{47}$ The capacity for a sense of justice is an activity of understanding and social engagement within a shared, cooperative enterprise with others as free and equal citizens. The second moral power is our capacity 'to have, to revise, and rationally to pursue a conception of the good' ${ }^{48}$

Our moral powers make possible the opportunities for citizens to endorse reasonable comprehensive doctrines and these powers may help us link political liberalism with private law. Ripstein argues:

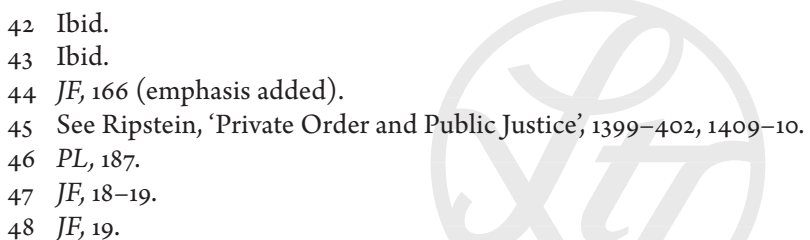


setting and pursuing your own conception of the good is the most important exercise of your freedom, because you are the person who sets your own path in life. No other person can take it upon themselves to choose for you, precisely because it is your life. From the inside, as you set and pursue particular purposes, you think of them as being not just your conception of the good, but good. ${ }^{49}$

The moral powers make possible the exercise of individual freedom. This is an activity of importance for citizens that they develop qua individuals. The special responsibility of each citizen for his or her own life places constraints on the means available for those purposes. Ripstein continues:

my special responsibility for my life is only consistent with your special responsibility for yours if each of us is required to forbear from using the other, or from using means belonging to the other, in pursuit of our purposes. That is the very thing that the familiar departments of private law articulate ... Articulating those relations requires an account of how people can have means of their own, consistent with the independence of each person from the others. That is just what the law of contract, tort, and property do..$^{50}$

The private domain serves an important role in developing the exercise of the moral powers of citizens that helps secure their independence as free persons. ${ }^{51}$ This also benefits their pursuits in both public and private dimensions as well as each type of responsibility.

Rawls's political liberalism can connect and support a space for private law although this requires some element of interpretive construction given the absence of any unambiguous commentary. One possibility considers his two types of obligation which signify two standpoints citizens should occupy. The first is the citizen as a member of a collective where, for example, members construct an overlapping consensus from public reasons that can be endorsed by everyone. This is the standpoint of the public law. The second standpoint is the citizen as an individual engaged in activities regulated by the private law. This possible connection of political liberalism to the private law requires that these two standpoints are complimentary, avoid incoherence, provide fair terms of cooperation and where neither standpoint is 'exempt from justice. ${ }^{52} \mathrm{~A}$ second possibility is that a sphere of private law helps enable the flourishing of each citizen's two moral powers by providing a space for their individual development. These possibilities overlap: the existence of different types of obligations leading to two standpoints is consistent with endorsing a non-public space where citizens can develop their moral powers.

If we accept these background considerations, it becomes clear that political liberalism and the private law can be linked. But can this link be improved on terms Rawls might accept? This is examined in the following section where I argue that we can im-

49 Ripstein, 'Private Order and Public Justice', 1403.

50 Ibid.

51 See ibid., 1438 ('The division of responsibility shows how just institutions, both public and private, enable free persons to be independent together').

$52 J F, 166$. 
prove the connection between political liberalism and private law if we revise part of Rawls's account to incorporate capabilities.

\section{Capabilities and the Social Minimum}

Rawls argues that the private sphere cannot be inconsistent or exempt itself from 'the content and application of the conception of justice and its principles.53 This does not deny a space for private law nor require uniformity between the public and private spheres. Rawls does require that each sphere is at least consistent with 'the conception of justice and its principles' set out in his political liberalism. I consider here how this might apply better in the private sphere than found in Rawls's work.

One important link between political liberalism and private law is that the latter can foster the exercise of our moral powers and development of individual freedom. This link can be improved by supplementing Rawls's account with a restatement of the social minimum in terms of a capabilities threshold. The capabilities approach focuses on an individual's ability to do or be and its aims to provide an account of well-being in terms of freedom..$^{54}$

I am not the first to argue for incorporating the capabilities approach into a revised political liberalism. Martha Nussbaum argues that Rawls's contractarianism undermines his commitment to the idea of the citizen conceived as free and equal. This is because contractarianism assumes a rough equality in capacity and bargaining position for citizens that is too often absent in practice. ${ }^{55}$ Nussbaum recommends incorporating capabilities into Rawls's account as an overlapping consensus that can be endorsed by every citizen. ${ }^{56}$

While I agree that political liberalism and capabilities are compatible, I believe their connection is best found elsewhere. Reconsider the requirement that every citizen is guaranteed a social minimum of primary goods. This minimum demarcates a threshold of primary good attainment across a range of different considerations, including (a) basic rights and liberties, (b) freedom of movement and choice of occupation, (c) political and economic freedoms, (d) income and wealth and (e) 'the social bases of self-respect.'.57 Together, this threshold of primary goods attainment - the social minimum - represents a package of essential rights and freedoms, opportunities, basic needs and self-respect.

Nussbaum's capabilities approach captures a similar conception in a more robust alternative. She provides a list of ten capabilities, including Life: Bodily Health; Bodily Integrity; Senses, Imagination, Thought; Emotions; Practical Reason; Affiliation; Other

Ibid.

See Martha C. Nussbaum, Creating Capabilities: The Human Development Approach (Cambridge: Harvard University Press, 2011).

Martha C. Nussbaum, Frontiers of Justice: Disability, Nationality, Species Membership (Cambridge: Harvard University Press, 2006): 29, 31-3, 66-67, 88-90, 108-13.

Nussbaum, Frontiers of Justice, 70.

$P L, 110$. 
S pecies; Play and Control over One's Environment..$^{58}$ Neither the capabilities on this list nor the social minimum is designed to offer a complete account of social justice on their own. Instead, each is an account of 'minimum core social entitlements.59 While both capabilities and the social minimum of primary goods capture similar kinds of goods, capabilities are more robust and provide a greater specification of their importance for human flourishing. For example, capabilities can address goods that are compelling and not included by Rawls's primary goods, such as leisure and our relation to the natural environment. $^{60}$

One benefit is that incorporating these goods into Rawls's list would not create incoherence with his understanding of political liberalism elsewhere. ${ }^{61}$ Restating primary goods in terms of capabilities, following Amartya Sen, is 'not a fundamental departure from Rawls's own programme, but mainly an adjustment.'.2 A second benefit is that the primary goods understood as capabilities would help it account for individual welfare better than Rawls's resource-based account. ${ }^{63}$ Sen says:

Some primary goods (such as 'income and wealth') are no more than means to real ends ... Other primary goods (such as 'the social basis of self-respect' to which Rawls makes an explicit reference) can include aspects of the social climate, even though they are generalized means (in the case of 'the social basis of self-respect' means to achieving self-respect). Still others (such as 'liberties') can be interpreted in different ways: either as means (liberties permit us to do things that we may value doing) or as the actual freedom to achieve certain results. ${ }^{64}$

58 Martha C. Nussbaum, Women and Human Development: The Capabilities Approach (Cambridge: Cambridge University Press, 2000): 78-80.

59 See Nussbaum, Frontiers of Justice, 78; Nussbaum, Creating Capabilities, 62; Martha C. Nussbaum, 'Capabilities and Human Rights', Fordham Law Review 66 (1997): 273-300; Martha C. Nussbaum, 'Capabilities, Entitlements, Rights: Supplementation and Critique', Journal of Human Development and Capabilities 12 (2011): 23-37 and Amartya Sen, 'Elements of a Theory of Human Rights', Philosophy and Public Affairs 32 $(2004): 315-56$.

60 My position is critical of what is in Rawls's list of primary goods in an internal critique. My claim is that capabilities not only capture the contents of Rawls's list, but they flesh them out much better. While Rawls was unconvinced that capabilities could be substituted for primary goods, this is because he is responding to a particular view of capabilities (i. e., Sen's capability approach) and not others like Nussbaum's approach. My claim is that Nussbaum's approach avoids Rawls's concerns about incorporating Sen's approach (which is different from Nussbaum's in important respects). Through this minor, but important, revision of Rawls's account we can have a more compelling interpretation of Rawls's theory in connection with private law. I am very grateful for an anonymous referee for helping me clarify this crucial point.

61 See Nussbaum, Frontiers of Justice, 116, 141; Nussbaum, Women and Human Development, 68; Amartya Sen, 'Well-Being, Agency and Freedom: The Dewey Lectures 1984', Journal of Philosophy LXXII (1985): 199-201 and T.M. Scanlon, 'Value, Desirem and Quality of Life' in Martha C. Nussbaum and Amartya Sen (eds), The Quality of Life (Oxford: Oxford University Press, 1993): 185-200, at 197-99.

62 Sen, The Idea of Justice, 66.

63 Nussbaum, Frontiers of Justice, 71-74, 114, 124-25. See Nussbaum, Creating Capabilities, 48-62; Amartya Sen, Development as Freedom (Oxford: Oxford University Press, 1999): 56; Amartya Sen, Inequality Reexamined (Oxford: Oxford University Press, 1995): 33; Amartya Sen, The Idea of Justice (London: Allen Lane, 2009): 238 and Amartya Sen, 'The Economics of Happiness and Capability' in Luigino Bruni, Flavio Comim and Maurizio Pugno (eds), Capabilities and Happiness (Oxford: Oxford University Press, 2008): 16-27, at 24-25.

64 Sen, Development as Freedom, 306-7. 
Rawls conceives primary goods instrumentally as a means of satisfactory human living, but not its end. ${ }^{65}$ Sen argues this fails to capture the important distinction between 'doing something' and 'being free to do that thing' that is possible by restating primary goods in terms of capabilities. ${ }^{66}$ Moreover, this restatement of primary goods as capabilities would have the further benefit of revisability. This is because capabilities are a product of discursive construction over time and no list is set in stone unlike Rawls's fixed list of primary goods. Any list of capabilities is not 'final', says Nussbaum, because 'if it turns out to lack something that experience shows to be a crucial element of a life worthy of human dignity, it can always be contested and remade. ${ }^{67}$ Capabilities are better placed to account for the evolving, multidimensional nature of human flourishing than primary goods. ${ }^{68}$

Rawls considers revising the primary goods in terms of capabilities as recommended by Sen. Rawls accepts some degree of overlap between them and states: 'I agree with Sen that basic capabilities are of first importance and that the use of primary goods is always to be assessed in the light of assumptions about those capabilities' ${ }^{69}$ Rawls says:

it should be stressed that the account of primary goods does take into account, and does not abstract from, basic capabilities: namely, the capabilities of citizens as free and equal persons in virtue of their two moral powers. It is these powers that enable them to be normal, and fully cooperating members of society over a complete life and to maintain their status as free and equal citizens ... These remarks locate the role of primary goods within the framework of justice as fairness as a whole ... we see that it does recognize the fundamental relation between primary goods and persons' basic capabilities. In fact, the index of those goods is drawn up by asking what things, given the basic capabilities included in the (normative) conception of citizens as free and equal..$^{\circ}$

While Rawls admits broad congruence between his primary goods and Sen's conception of capabilities, there is a crucial difference for Rawls in the more determinate nature of primary goods making them easier to apply. ${ }^{71}$ Rawls argues that capabilities such as 'well-being' are 'not sufficiently determinate' and more difficult to apply in practice. ${ }^{72}$ For Rawls, primary goods and not capabilities satisfy the publicity criterion whereby claims of justice are easily accessible and verifiable by all. ${ }^{73}$ Rawls's criticism of Sen's account is less of a problem for Nussbaum's capabilities approach which provides a list. ${ }^{74}$

65 See Sen, The Idea of Justice, 234.

66 Ibid., 234, 237. See Sen, 'Well-Being, Agency and Freedom', 198-99.

67 Nussbaum, Creating Capabilities, 15. See Sen, The Idea of Justice, 238.

68 Rawls is not explicit about whether his list of primary goods is revisable over time. See TJ, 54-55, 348-49; JF, 58-59 and $P L, 188-89$.

$69 P L, 183$.

$70 \mathrm{JF}, 169-70$.

71 See $P L, 185$.

72 John Rawls, A Theory of Justice (Cambridge: Harvard University Press, 1971): 283. See Sebastiano Maffetone, Rawls (Cambridge: Polity, 2010): 217.

73 Rawls, 'Social Unity and Primary Goods', 169-70 and LP, 13.

74 See Samuel Freeman, 'Frontiers of Justice: The Capabilities Approach vs. Contractarianism', Texas Law Review 85 (2006): 419-20. 
The more crucial reason for Rawls's rejection of S en's proposed revision of primary goods is because Rawls considers Sen's idea of capabilities as a comprehensive doctrine. Rawls argues that political liberalism 'presupposes no particular comprehensive view, and hence may be supported by an enduring overlapping consensus of reasonable doctrines' ${ }^{75}$ One potential benefit of revising the primary goods might appear to be to provide a more robust account, but Rawls fears capabilities are too thick for general acceptance by any comprehensive doctrine. He says that primary goods must be sufficiently thin so that they are 'not anyone's idea of the basic values of human life and must not be so understood'. ${ }^{6}$ Only primary goods are 'mutually acceptable to citizens generally.77

This rejection of capabilities assumes that capabilities form an overly substantive view about the good that is compatible with every comprehensive doctrine. Of course, Rawls is not opposed to any endorsement of the good given his support for primary goods. Moreover, he is clear about the overlap between primary goods and capabilities. But what Rawls needs to argue is not that primary goods are sufficiently 'thin', but rather that capabilities are too 'thick'. The capabilities approach is not a fully comprehensive doctrine as even its leading critics accept. ${ }^{78}$ Capabilities need not be unacceptable by every comprehensive doctrine.

Both Nussbaum and Sen argue that Rawls's political liberalism can and should incorporate capabilities, but in different ways with contrasting approaches. Nussbaum's claim is that capabilities can be the subject of an overlapping consensus endorsed by any comprehensive doctrine as an addition to political liberalism. Sen argues that political liberalism should be revised by restating the primary goods as capabilities. Rawls rejects Sen's recommendations primarily because of the concerns it is too ill-defined for practical application and so conceptually robust it would fail to gain the support of every comprehensive doctrine.

Rawls's concerns about incorporating Sen's particular understanding of capabilities might be overcome by using Nussbaum's instead. Nussbaum's approach uses a list of ten capabilities which helps avoid the problem of specification. Plus, Nussbaum's approach focuses on the attainment of some threshold of capability satisfaction closely connected to Rawls's idea of the social minimum. Sen's approach is different and lacks the same focus on threshold satisfaction and instead has a more goal-oriented view of capabilities not unlike some comprehensive doctrines. So Rawls's primary goods should be revised by a conception of capabilities more in the spirit of Nussbaum's approach than Sen's although not incorporating her approach as she recommends. I do not argue for Nussbaum's particular formulation of her approach, but rather some conception of capabilities that shares her wide range of capabilities focused on threshold satisfaction. This is because there are some aspects of Nussbaum's specification of capabilities that may ren-

$75 \mathrm{JF}, 37$.

$76 P L, 188$.

77 Ibid.

78 See Thomas Pogge, 'A Critique of the Capability Approach' in Henry Brighouse and Ingrid Robeyns (eds), Measuring Justice: Primary Goods and Capabilities (Cambridge: Cambridge University Press, 2010): 17-60, at $19-20$. 
der incompatible with some comprehensive doctrines. ${ }^{79}$ This is not an argument against the incorporation of capabilities within political liberalism, but rather support for a less controversial approach.

The wider benefits for this restatement of political liberalism are that it will improve its connection to the private law. If the private law is a sphere where citizens can exercise and develop their moral powers as free and equal individuals, this helps support the development of moral powers by citizens more widely. The importance of this development is it promotes satisfaction of the basic minimum of primary goods and the ability of citizens to engage in public reason when constructing an overlapping consensus. Restating the primary goods as capabilities provides a more substantial and flexible approach to capturing the exercise of our moral powers across a wider array of indicators that usefully fleshes out the contours of the social minimum. This offers a more robust perspective from which to consider the private law in light of political liberalism than currently available from Rawls.

\section{Conclusion}

Rawls's political liberalism is a dominant theory about justice whose application to matters of private law has been relatively neglected. This essay addresses this gap by arguing for a revision of Rawls's theory through incorporation of capabilities. This revision does not render his political liberalism incoherent, but it does better substantiate the importance of the moral powers for citizens as free and equal across the public and private spheres. The relation of capabilities to private law is an area still to be explored much further. ${ }^{80}$ Nonetheless, this essay offers a new perspective about how political liberalism and capabilities can be incorporated within a coherent account and how it can help us address the private law better than currently possible from Rawls's political liberalism while remaining true to its fundamental commitments. ${ }^{81}$

PROF. THOM BROOKS

Dean of Durham Law School, Chair in Law and Government,

Durham Law School, Durham University, Durham, DH1 3 LE, United Kingdom,

Website: http://thombrooks.info, Twitter: @thom_brooks

One example is Nussbaum's specifying that the capability of 'bodily integrity' includes 'choice in matters of reproduction'. While I favour this definition, it is unlikely to command the support of all Catholic citizens and Catholicism is a reasonable comprehensive doctrine. See Nussbaum. Women and Human Development, 78 .

80 See Lyn K. L. Tjon Soei Len, The Effects of Contracts Beyond Frontiers: A Capabilities Perspective on Externalities and Contract Law in Europe (Ph. D., Faculty of Law, University of Amsterdam, 2013).

81 I acknowledge my thanks to Samuel Freeman, Martha Nussbaum and Samuel Scheffler for comments on an earlier draft. 